\title{
DETECTING DifFERENCES AT A SELECTED SHOOTING WEAPON AND ITS FREELY AVAILABLE COPIES
}

\author{
Michal Gracla, Michaela Mikulicova \& Zdenek Malanik
}
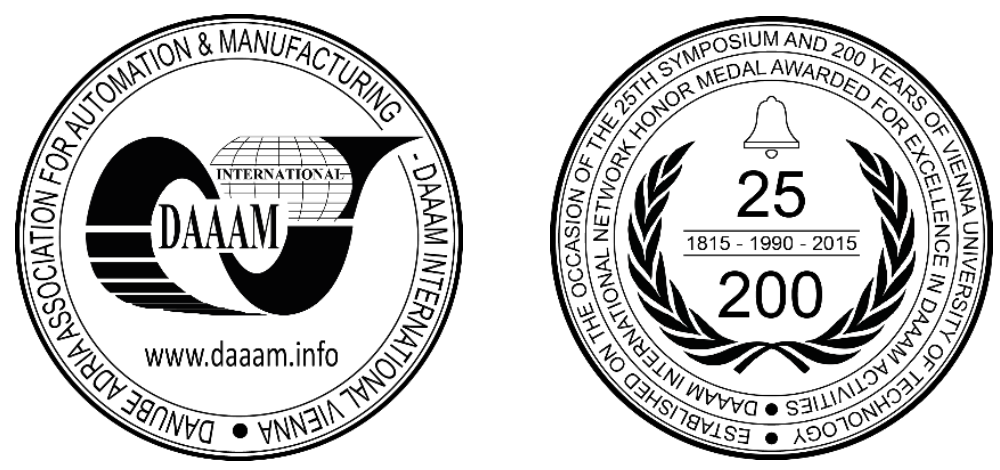

This Publication has to be referred as: Gracla, M[ichal]; Mikulicova, M[ichaela] \& Malanik, Z[denek] (2018). Detecting Differences at a Selected Shooting Weapon and Its Freely Available Copies, Proceedings of the 29th DAAAM International Symposium, pp.1139-1143, B. Katalinic (Ed.), Published by DAAAM International, ISBN 978-3-90273420-4, ISSN 1726-9679, Vienna, Austria

DOI: $10.2507 / 29$ th.daaam.proceedings. 163

\begin{abstract}
The topic of shooting weapons is very expended. Some people say that shooting weapons are dangerous. Other people say that people who own shooting weapons are dangerous. The truth lies probably somewhere in the middle. However, the issue of shooting weapons still needs to be addressed. Awareness of their occurrence, the wounded effect, and the appearance needs to be extended even among the lay public. Nowadays, it is needed twice. People are misinformed by media or they know incomplete or even the twisted truth. Most laymen cannot tell what is possible and what is already not possible from those information. Most shooting weapons look as the same but they can be only so-called "toys" or freely available copies.
\end{abstract}

Keywords: shooting weapon; copy; expansion weapon; airsoft weapon

\section{Introduction}

The shooting weapons of category D (according to the Czech legislation [1]) are frequently used as an available and cheap alternative of the weapons of category B. To own a shooting weapon of category B, it is necessary to fulfil conditions provided by law and to own a gun licence. Each weapon of category B is registered in the police database, and its possession is strictly regulated [1]. On the contrary, the weapons of category D, such as airsoft guns and expansion guns, are widely available and there are no special conditions for their possession. In many cases, these guns are visual copies of the weapons of category B; however, their function and properties are quite different.

The crucial difference between the weapons of category B and their copies are consequences of shooting. These consequences have been widely studied in [2], [3], [4], [5]. Most studies [6], [7], [8], [9], [10], [11], [12] have been focused on the wounding potential which is the ability to cause injury to the human body. Although the weapons of category D are widespread, their research is quite neglected. It is worthwhile to note that the weapons of category D are often used for self-defence. This is caused especially by their visual similarity with the weapons of category B. In a critical situation, it can be difficult to differentiate whether an attacker holds a shooting weapon of category B or its less dangerous copy of category D, as mentioned in [13]. As a result, the weapons of category D are often bought by people who want to own a gun but cannot own a gun licence. 
Some of these people can be criminals who use the visual similarity of the weapons of category D to commit criminal activities such as gas station robbery, disorderly conduct and other violent crimes [13], [14], [15], [16], [17], [18]. The purpose of this paper is to determine whether it is possible to differentiate between the weapons of category B and their copies of category $\mathrm{D}$ based on the visual evaluation.

\section{Investigated weapons}

Three visually similar weapons were studied: one weapon of category B and its two copies of category D. The weapon of category B was the CZ 75 B firearm, the weapons of category D were the KP-09 CZ 75 airsoft gun and the Kimar CZ75 expansion weapon.

Fig. 1 shows the CZ 75 B firearm which is a very popular gun not only in the Czech Republic but also abroad. This gun has a calibre of $9 \mathrm{~mm}$ and is designed for security forces and sport. Its advantages are a grip for both right and lefthanded, double-stack magazine and high shooting accuracy. Most of the produced guns were exported abroad, but the gun was protected by the patent only in former Czechoslovakia. Consequently, the number of copies has been created all over the world. It is worthwhile to note that the CZ 75 B firearm is one of the three most copied guns nowadays.
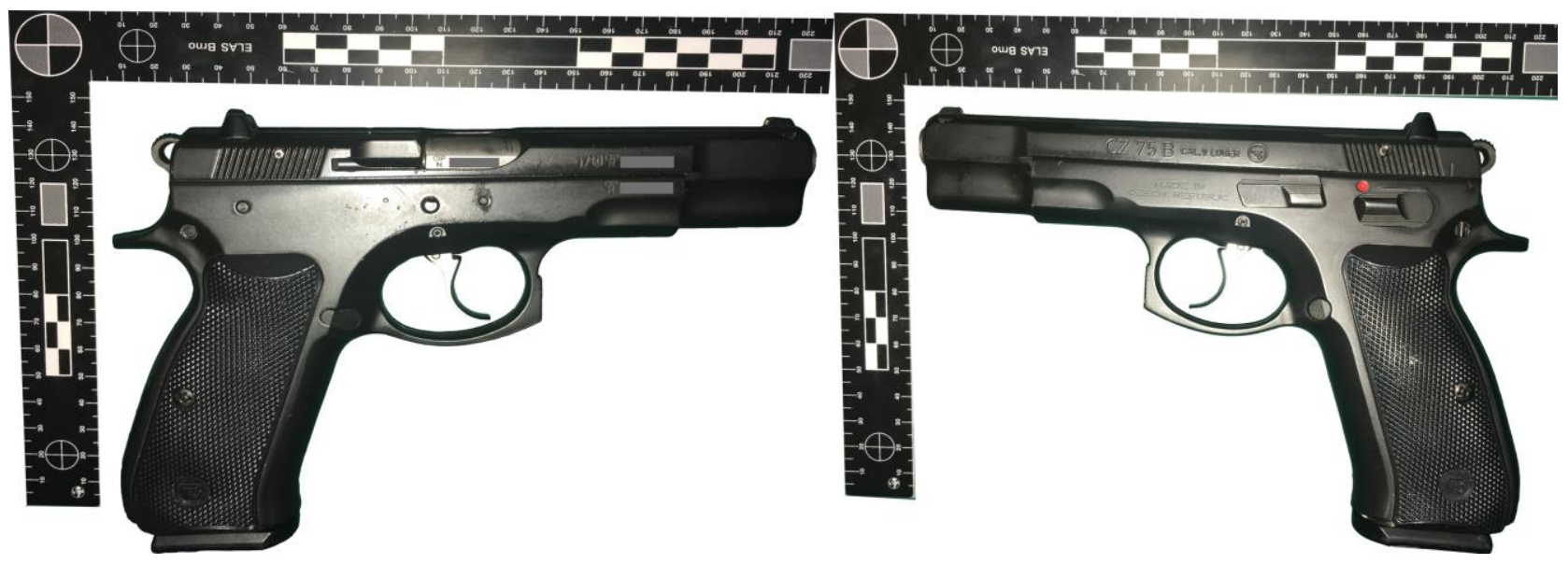

Fig. 1. CZ 75 B firearm

Airsoft guns are air guns which shoot spherical bullets instead of common projectiles. There are three basic types of shooting mechanisms:

- extension of a spring,

- gas container inserted into the gun,

- gas container inserted into the magazine.

In our experiment, the KP-09 CZ 75 airsoft gun was used, as shown in Fig. 2. This all-metal gun works on a BlowBack system which means that the gun has a movable slide. Because of this slide, the KP-09 CZ 75 airsoft gun creates the illusion of "lethal" firearm and allows semi-automatic shooting. The capacity of the magazine is 28 spherical bullets.
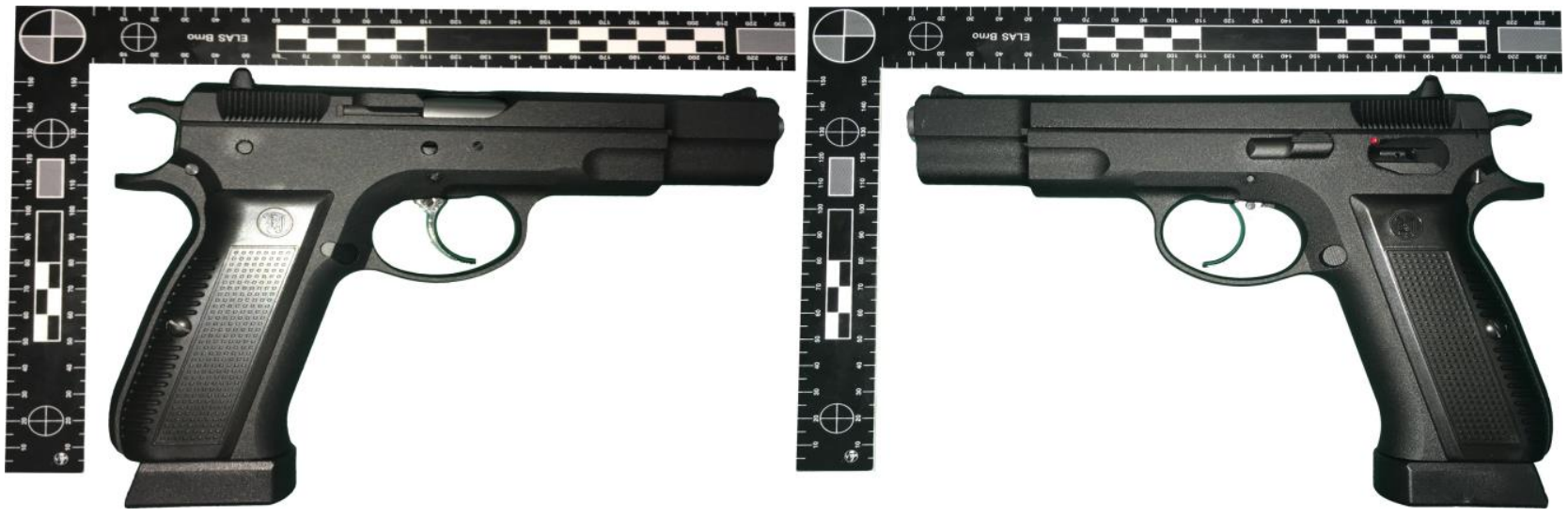

Fig. 2. KP-09 CZ 75 airsoft gun 
Expansion weapons are firearms which use bag-cartridges instead of common cartridges. This means that expansion weapons do not shoot projectiles. There are three basic types of bag-cartridges:

- acoustic bag-cartridge,

- acoustic bag-cartridge with a light effect (flame burst),

- bag-cartridge combining an acoustic effect with a chemical irritant (e.g. technical pepper).

Expansion weapons always have a movable slide; however, their construction does not allow the insertion of common cartridges. Fig. 3 shows the Kimar CZ-75 expansion weapon. This all-metal weapon is self-charging, and its magazine has the capacity of 10 bag-cartridges.

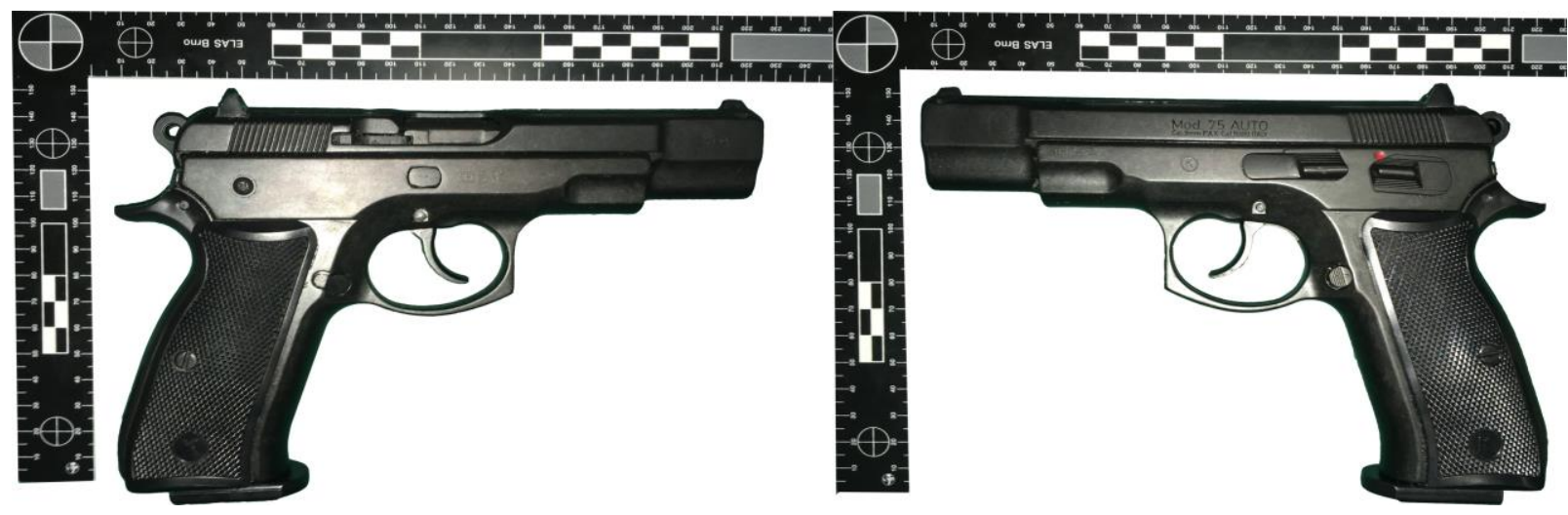

Fig. 3. Kimar CZ-75 expansion gun

\section{Results}

The aim of the research was to determine whether it is possible to differentiate between the weapons of category B and their copies of category D during a critical situation. Weapons were analysed at laboratory conditions to investigate differences precisely.

\begin{tabular}{|l|l|l|l|}
\hline \multicolumn{1}{|c|}{ Marker } & \multicolumn{1}{|c|}{ Firearm } & \multicolumn{1}{c|}{ Airsoft gun } & \multicolumn{1}{c|}{ Expansion weapon } \\
\hline Hammer & Rounded with the hole & Into the arc & Rounded with the hole \\
\hline Ejection port & $\begin{array}{l}\text { The barrel and the ejector } \\
\text { are visible }\end{array}$ & Imitation of the ejector & $\begin{array}{l}\text { The barrel and the ejector } \\
\text { are visible }\end{array}$ \\
\hline Muzzle & $\begin{array}{l}\text { The barrel protrudes } \\
\text { slightly }\end{array}$ & $\begin{array}{l}\text { The barrel protrudes } \\
\text { significantly }\end{array}$ & $\begin{array}{l}\text { The barrel protrudes } \\
\text { slightly }\end{array}$ \\
\hline $\begin{array}{l}\text { Slide stop (on the } \\
\text { right) }\end{array}$ & $\begin{array}{l}\text { The standard output of the } \\
\text { slide stop }\end{array}$ & $\begin{array}{l}\text { The false output of the slide } \\
\text { stop }\end{array}$ & $\begin{array}{l}\text { The oval output of the slide } \\
\text { stop }\end{array}$ \\
\hline Logo on grip & Without logo & Logo on the pistol grip & Without logo \\
\hline Slide (text) & Gun label, calibre and logo & Without label & Gun label \\
\hline Trigger guard & $\begin{array}{l}\text { The front side of the trigger } \\
\text { guard is flat, the rest of the } \\
\text { guard is rounded }\end{array}$ & The trigger guard is rounded & $\begin{array}{l}\text { The front side of the trigger } \\
\text { guard is flat, the rest of the } \\
\text { guard is rounded }\end{array}$ \\
\hline $\begin{array}{l}\text { Slide stop (on the } \\
\text { left) }\end{array}$ & Square & Small rounded & Standard rounded \\
\hline Safety (on the left) & Standard & Smaller and rounded & Standard \\
\hline Grip Safety & Shorter, slightly bent down & Longer and straight & Shorter and straight \\
\hline
\end{tabular}

Table 1. Description of identified markers of investigated weapons

Components (markers) differing at first sight were identified and compared. Results can be seen in Table 1 and Fig. 4. The most significant markers are highlighted in red. These markers can be identified with the highest possibility in a critical situation. Markers highlighted in blue are less significant because they can be easily overlooked or even removed by a modification.

Although feet of the magazines can also be identified as the significant markers, they were not included. This results from their variability - their size and shape can be easily modified, so they are not suitable for the differentiation of weapons. 

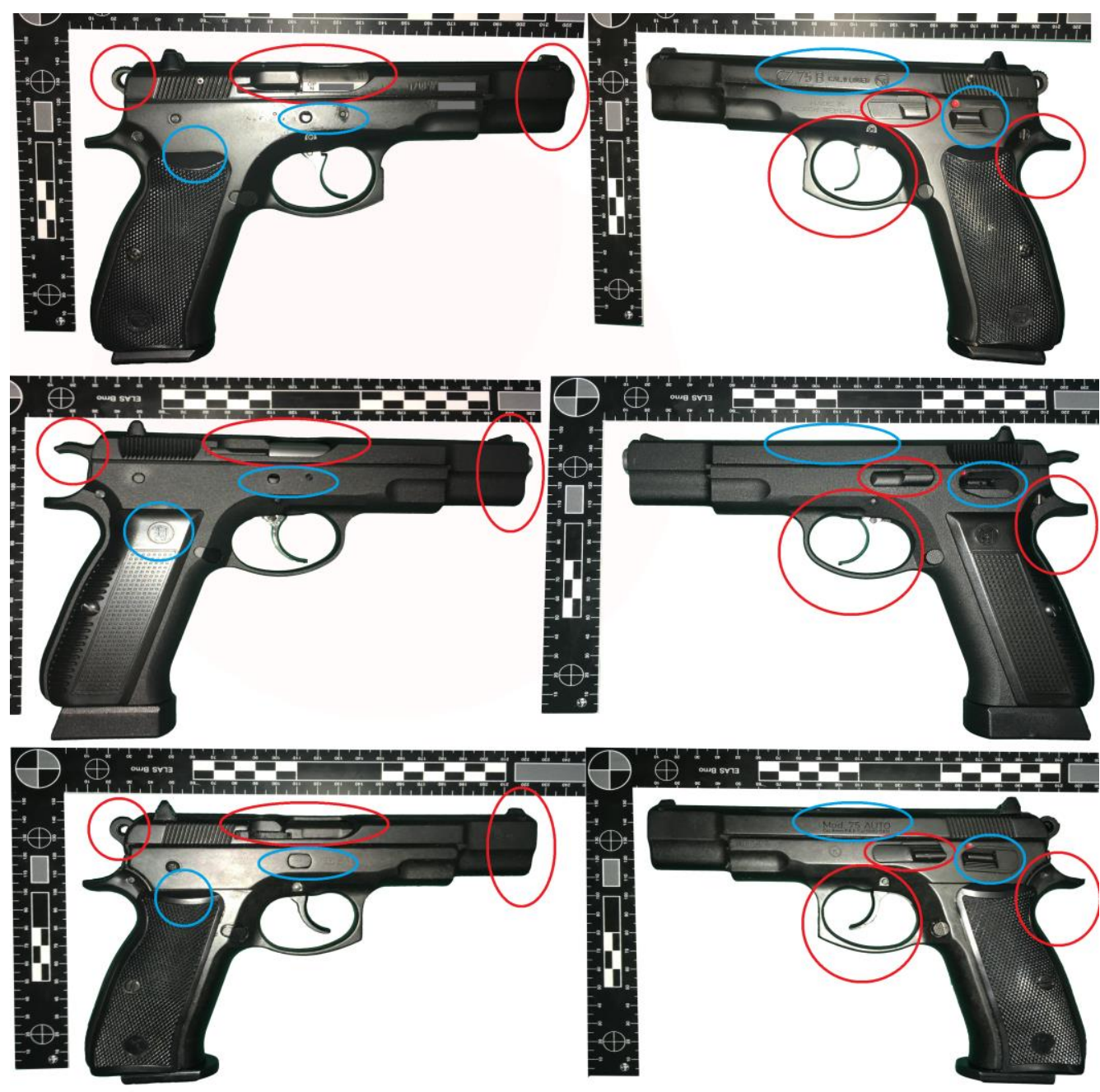

Fig. 4. Graphical description of identified markers of investigated weapons

\section{Conclusion}

The purpose of this paper was to determine whether it is possible to differentiate between the weapons of category B and their copies of category D based on the visual evaluation. To analyse differences between weapons of category B and D, firearm CZ 75 B and its two copies (airsoft gun and expansion weapon) were studied. Components (markers), which help to differentiate between investigated weapons, were identified.

From the analysis results that the differentiation of firearms from their freely available copies is extremely difficult. Found differences are hardly identifiable even under normal conditions. It can be said that in critical situations or under impaired visual conditions (e.g. night, poor lights, rain, smoke), weapons cannot be differentiated at all. It should be borne in mind that people in a critical situation focus primarily on the presence of a weapon, not on its differentiation.

It was found that the weapons of category D are inappropriate mean of self-defence. Owners of these weapons usually do not know how to handle a weapon. Moreover, they may not realize the risks which arise from the use of weapons. For example, there may be the situation in which an attacker uses a firearm in response to the thread of the weapon of category D without being able to recognize that it is not a "lethal" firearm. Therefore, the weapons of category D should not be used for self-defence. It is always better to lose money than life. The weapons of category D can be recommended only for the training of weapons handling.

The limitation of this study is obvious: the determination of differences is subjective, and another research team may have slightly different results. Clearly, more research of differentiation between the weapons of category B and their copies of category D is needed. One of the challenges for future research is to analyse the differentiation under special conditions and in critical situations. Moreover, the larger sample of weapons should be investigated in future research.

\section{Acknowledgments}

This work was supported by the Internal Grant Agency of Tomas Bata University under the project No. IGA/FAI/2018/014. 


\section{References}

[1] „Act on Firearms and Ammunition“, (2002). p. 76. Zákon o střelných zbraních a střelivu, (2002). p. 76

[2] Jorgensen, J. J., Naess P. A. \& Gaarder Ch. (2016). Injuries caused by fragmenting rifle ammunition. Injury, ISSN 00201383, pp. 1951-1954, DOI: 10.1016/j.injury.2016.03.023.

[3] Hanna, T. N. et al. (2015). Firearms, bullets, and wound ballistics: An imaging primer. Injury, ISSN 00201383, pp. 1186-1196, DOI: 10.1016/j.injury.2015.01.034.

[4] Riddez L. (2014). Wounds of war in the civilian sector: principles of treatment and pitfalls to avoid. European Journal of Trauma and Emergency Surgery, ISSN 1863-9933, pp. 461-468, DOI: 10.1007/s00068-014-0395-6.

[5] Tikal, F. (2015). Evolution of indoor bullet trap design. 26th DAAAM International Symposium on Intelligent Manufacturing and Automation, 2015, ISSN 17269679, ISBN 978-390273407-5 pp. 385-390. DOI: 10.2507/26th.daaam.proceedings.052.

[6] Šafr, M. \& Hejna P. (2010). Gunshot wounds, ISBN: 978-80-7262-696-0, Praha: Galén. Šafr, M. \& Hejna P. (2010). Střelná poranění, ISBN: 978-80-7262-696-0, Praha: Galén.

[7] Juříček, L. (2016). Comparison of crossbow arrow and small-calibre projectile charge calibre 22 Long Rifle penetration depth into alternative material biological tissues in experimental wounded ballistics. Bezpečnostní management v regionech. pp. 1-12. Juříček, L. (2016). Porovnání hloubky vniku šípu kuše a střely náboje ráže 22 Long Rifle do bloku náhradního materiálu biologických tkání v experimentální ranivé balistice. Bezpečnostní management $\mathrm{v}$ regionech. pp. 1-12.

[8] Juříček, L., Plíhal, B. \& Komenda, J. (2003). Prediction of ballistic bodies penetration depth into alternative material biological tissues in a ballistic experiment, pp. 23-35. Juříček, L., Plíhal, B. \& Komenda, J. (2003). Predikce hloubky vniku balistických těles do bloku náhradního materiálu biologických tkání v balistickém experiment, pp. 23-35.

[9] Gracla, M., Chocholatý, A. \& Malanik, Z. (2017). Analysis of the wounding effect of elementary weapons of category D. Sborník př́spěvků konference Expert Forensic Science Brno 2017 (ExFoS 2017), ISBN 978-80-2145459-0, Bradáč, A. \& Křižák, M. (Ed.), pp. 327-336. Gracla, M., Chocholatý, A. \& Malanik, Z. (2017). Analýza ranivého účinku základních zbraní kategorie D. Sborník př́íspěvků konference Expert Forensic Science Brno 2017 (ExFoS 2017), ISBN 978-80-214-5459-0, Bradáč, A. \& Křižák, M. (Ed.), pp. 327-336.

[10] Mikulicova, M. et al. (2017). Comparison of depth of incomplete penetration for different types of pellets for shooting weapon of category D. International Conference on Military Technologies (ICMT), Brno: IEEE, ISBN 978-153861988-9, Krivanek V. (Ed.), pp. 66-69, DOI: 10.1109/MILTECHS.2017.7988732.

[11] Gracla, M. \& Křesálek, V. (2017). Determining the Wounding Potential of Shooting Weapons in the Course Forensic Science at the Faculty of Applied Informatics Tomas Bata University in Zlin. The Turkish Online Journal of Educational Technology, ISSN 21467242, pp. 802-810.

[12] Gracla, M. et al. (2017). Comparison of Wounded Potential of Weapons of Category D through Clothing, Krizové řízení a řešení krizových situací, Uherské Hradiště, ISBN 978-80-7454-717-1, Konečný, J. \& Adamec, V. (Ed.), pp. 94-104. Gracla, M. et al. (2017). Komparace ranivého potenciálu zbraní kategorie D přes oděvní material, Krizové řízení a řešení krizových situací, Uherské Hradiště, ISBN 978-80-7454-717-1, Konečný, J. \& Adamec, V. (Ed.), pp. 94-104.

[13] news, (2018). Someone used a "lethal" weapon and shot the player to the chest during airsoft game in Milovice. [online]. Available: https://www.novinky.cz/krimi/485319-pri-airsoftu-v-milovicich-nekdo-pouzil-skutecnouzbran-a-prostrelil-hraci-hrudnik.html. novinky.cz, (2018). Při airsoftu v Milovicích někdo použil skutečnou zbraň a prostř̌elil hráči hrudník, [online]. Dostupné: https://www.novinky.cz/krimi/485319-pri-airsoftu-v-milovicichnekdo-pouzil-skutecnou-zbran-a-prostrelil-hraci-hrudnik.html.

[14] Gupta, D., Tailor, T. D., Francis, C., Kanal, K. \& Klesert, T. (2018). Penetrating injury from plastic airsoft pellet shown beam-hardening artefact on computer tomography. Retinal Cases and Brief Reports, ISSN 19371578, pp. 346-348, DOI: 10.1097/ICB.0000000000000500.

[15] Dandu, K. V., Carniol, E. T., Sanghvi, S., Beredes, S. \& Eloy J. A. (2017). A 10-year analysis of head and neck injuries involving nonpowder firearms. Otolaryngology - Head and Neck Surgery, ISSN 01945998, pp. 853-856, DOI: $10.1177 / 0194599817695546$.

[16] Nieh, H.-M. \& Liu, C.-Y. (2018). A novel scoring system for the gun shoot of emulated war games. ICIC Express Letters, ISSN 21852766, pp. 635-640, DOI: 10.24507/icicelb.09.07.635.

[17] Khalaily, S., Tsumi, E., Lifshitz, T., Kratz, A. \& Levy, J. (2018). Airsoft gun-related ocular injuries: long-term follow-up. Journal of AAPOS, ISSN 10918531, pp. 107-109, DOI: 10.1016/j.jaapos.2017.10.019.

[18] Pircher, R., Große Perdekamp, M., Thierauf-Emberger, A., Kramer, L., Pollak, S. \& Geisenberger, D. (2017). Wound morphology in contact shots from blank cartridge handguns: a study on composite models. International Journal of Legal Medicine, ISSN 09379827, pp. 1333-1339, DOI: 10.1007/s00414-017-1650-2. 